\title{
Analisis Kemampuan Berpikir Kreatif dan Komunikasi pada Penerapan Blended Project Based Learning Matakuliah Komunikasi Data dan Jaringan Komputer
}

\author{
Umi Kholifah $^{1}$, Muladi $^{2}$, Yoto $^{3}$ \\ ${ }^{1}$ Pendidikan Kejuruan-Universitas Negeri Malang \\ ${ }^{2}$ Teknik Elektro-Universitas Negeri Malang \\ ${ }^{3}$ Teknik Mesin-Universitas Negeri Malang
}

\begin{tabular}{l}
\hline INFO ARTIKEL \\
\hline Riwayat Artikel: \\
Diterima: 07-12-2018 \\
Disetujui: $15-03-2019$ \\
\hline
\end{tabular}

Kata kunci:

creative thinking;

communication;

berpikir kreatif;

komunikasi;

blended project based learning

\begin{abstract}
ABSTRAK
Abstract: This study aims to analyze the result of each indicator of creative thinking and communication and to know the difference in creative and communication thinking skills students in the application of Blended Project Based Learning in Data and Computer Networking courses. This study uses descriptive quantitative methods. The research subjects were PTI S1 students of the 2017. The results of the study are as follows most of the frequency of acquisition of indicators of creative thinking and communication, Offering B is higher than class C; the average Offering B has a higher level of creative thinking and communication skills than class $\mathrm{C}$ which is 88.20 for creative thinking and 89.51 for communication.
\end{abstract}

\begin{abstract}
Abstrak: Penelitian ini bertujuan untuk menganalisis perolehan masing-masing indikator berpikir kreatif dan komunikasi serta mengetahui perbedaan kemampuan berpikir kreatif dan komunikasi mahasiswa pada penerapan Blended Project Based Learning matakuliah Komunikasi Data dan Jaringan Komputer. Metode penelitian yang digunakan yaitu metode deskriptif kuantitatif. Subjek penelitian adalah mahasiswa S1 PTI angkatan 2017. Hasil penelitian adalah sebagai berikut sebagian besar frekuensi perolehan indikator berpikir kreatif dan komunikasi, Offering B lebih tinggi daripada kelas C; rata-rata Offering B memiliki kemampuan berpikir kreatif dan komunikasi lebih tinggi dibandingkan kelas $C$ yaitu sebesar 88,20 untuk berpikir kreatif, dan 89,51 untuk komunikasi.
\end{abstract}

\author{
Alamat Korespondensi: \\ Umi Kholifah \\ Pendidikan Kejuruan \\ Universitas Negeri Malang \\ Jalan Semarang 5 Malang \\ E-mail: kholifahumi9@gmail.com
}

Sesuai dengan kurikulum Universitas Negeri Malang dan selaras dengan kurikulum perguruan tinggi yang ditetapkan Kemenristek Dikti, calon guru bidang kejuruan harus menguasai pengetahuan pendidikan dan pengetahuan keteknikan. Kumpulan matakuliah yang telah disesuaikan dengan semester yang dijalani mahasiswa adalah bentuk dari penyajian pengetahuan tersebut. Salah satu matakuliah yang dapat mendukung pengetahuan keteknikan mahasiswa S1 Pendidikan Teknik Informatika yaitu Komunikasi Data dan Jaringan Komputer yang memiliki 3 sks dan 4 jam studi. Sesuai kebijakan kurikulum jurusan Teknik Elektro mulai tahun 2014, matakuliah Komunikasi Data dan Jaringan Komputer yang awalnya terpisah antara teori dan praktikum akan dijadikan satu jam studi. Hal ini membawa dampak pada penggunaan jam studi yang semakin pendek sehingga materi dimampatkan. Selain itu, modul dan sistem pembelajaran yang diterapkan pada matakuliah Komunikasi Data dan Jaringan Komputer tidak berjalan secara maksimal. Course Management System (CMS) Edmodo hanya bersifat sebagai penampung tugas dan materi.

Berdasarkan keadaan tersebut dikembangkan sebuah pembelajaran yang dapat menyelesaikan problem tersebut. Pembelajaran yang dikembangkan pada matakuliah Komunikasi Data dan Jaringan Komputer adalah Blended Project Based Learning yang didukung oleh perangkat pembelajaran online dan offline. Perangkat pembelajaran online adalah web learning yang mengalami dimodifikasi dan berisi konten yaitu materi serta penilaian. Perangkat pembelajaran offline tersusun atas Satuan Acara Pembelajaran dan Lembar Kerja Mahasiswa. Selain dirancang untuk mengatasi masalah yang ada pada matakuliah Komunikasi Data dan Jaringan Komputer, Blended Project Based Learning dirancang untuk meningkatkan kemampuan abad 21 di bidang kompetensi yaitu kemampuan berpikir kritis, berpikir kreatif, komunikasi, dan kolaborasi. 
Pada abad 21 yang merupakan era globalisasi dan internasionalisasi ini, manusia dituntut untuk memiliki kecakapan abad 21 agar mampu menghadapi persaingan tersebut (Pheeraphan, 2015). Kecakapan utama yang harus dimiliki manusia pada abad 21 adalah kemampuan berpikir kritis (Thompson, 2011). Keterampilan berpikir kritis berhubungan dengan proses pemecahan masalah dalam kehidupan sehari-hari (Slameto, 2014). Berpikir kritis berkaitan dengan kegiatan eksplorasi ide, analisis data, pengambilan keputusan, evaluasi tindakan (Alias \& Ibrahim, 2015; Thompson, 2011). Kecakapan lain yaitu berpikir kreatif berkaitan dengan kemampuan untuk mengungkapkan kemungkinan baru, membuka sudut pandang luas, serta memuncul gagasan yang unik dan berbeda (Johnson, 2009). Berpikir kreatif dapat dikembangkan melalui lingkungan, program, guru, dan pembelajaran yang kreatif.

Dua kecakapan yang saling terhubung, yaitu komunikasi dan kolaborasi. Kemampuan komunikasi mencakup kemampuan untuk menyampaikan opini secara oral maupun tertulis yang bersifat persuasif dan memotivasi (Zubaidah, 2016). Komunikasi dapat terjalin secara efektif apabila individu juga dapat memosisikan diri sebagai pendengar aktif (Sari, 2016). Oleh karena itu, kemampuan komunikasi terbagi menjadi komunikasi lisan, tulisan, dan mendengarkan. Kolaborasi berkaitan erat dengan kolaborasi. Hal ini disebabkan jika kemampuan komunikasi yang efektif dibarengi dengan kemampuan kolaborasi maka akan mempermudah individu menghadapi persaingan di abad 21. Kolaborasi berkaitan dengan kemampuan untuk bekerjasama baik dalam satu kelompok atau kelompok lain (Sabirin, 2016).

Aspek kemampuan berpikir kritis, berpikir kreatif, komunikasi, dan kolaborasi diharapkan menunjukkan hasil yang tinggi setelah menerapkan Blended Project Based Learning. Penggunaan keempat aspek tersebut memerlukan banyak evaluasi karena memerlukan penyesuaian jika diterapkan pada lingkungan yang berbeda. Oleh karena itu, penelitian ini akan meneliti pada dua aspek, yaitu aspek keterampilan berpikir kreatif dan komunikasi. Analisis akan fokus pada indikator-indikator dua aspek tersebut. Dapat disimpulkan, tujuan penelitian yaitu menganalisis perolehan masing-masing indikator berpikir kreatif dan komunikasi serta mengetahui perbedaan kemampuan berpikir kreatif dan komunikasi pada mahasiswa S1 Pendidikan Teknik Informatika angkatan 2017 pada penerapan Blended Project Based Learning matakuliah Komunikasi Data dan Jaringan Komputer.

\section{METODE}

Pendekatan dalam penelitian ini termasuk pendekatan kuantitatif dengan jenis penelitian deskriptif. Penelitian ini bertujuan agar peneliti mendapat gambaran tentang tingkat kemampuan berpikir kreatif dan komunikasi pada penggunaan Blended Project Based Learning pada matakuliah Komunikasi Data dan Jaringan Komputer. Subjek yang digunakan pada penelitian ini yaitu mahasiswa S1 PTI 2017 yang mengikuti matakuliah Komunikasi Data dan Jaringan Komputer yang terdiri dari dua kelas, yaitu offering B dan offering C yang berjumlah masing-masing 39 orang. Instrumen penelitian yang digunakan untuk mengukur kemampuan berpikir kreatif adalah tes yang dibuat berdasarkan indikator kemampuan berpikir kreatif oleh Munandar (2008). Indikator tersebut meliputi berpikir lancar (fluency), berpikir luwes (flexibility), berpikir orisinil (originality), berpikir elaboratif (elaboration), dan berpikir evaluatif (evaluation).

Instrumen penelitian yang digunakan untuk mengukur kemampuan komunikasi adalah asesmen non tes berupa lembar observasi yang dibuat sesuai indikator kemampuan komunikasi. Komunikasi dibagi menjadi komunikasi lisan, komunikasi tulisan, dan keterampilan mendengarkan (Iriantara, 2014; Lunenburg, 2010; Santrock, 2012). Proses observasi untuk pengukuran kemampuan komunikasi akan dilakukan oleh dosen dan mahasiswa dengan metode self assesement dan peer assessment. Self assessment merupakan bentuk penilaian yang dilakukan oleh individu itu sendiri, sedangkan peer assessment akan dilakukan oleh anggota kelompok dan juga dosen. Hasil dari tes dan lembar observasi akan dianalisis secara deskriptif lalu dipresentasikan.

\section{HASIL}

\section{Analisis Indikator Kemampuan Berpikir Kreatif dan Komunikasi}

Berdasarkan hasil penelitian yang dilakukan diketahui bahwa kelas B mendapat persentase yang lebih tinggi untuk aspek flexibility dan elaboratif bila dibandingkan dengan kelas $\mathrm{C}$, sedangkan kelas $\mathrm{C}$ mendapat persentase yang lebih tinggi untuk aspek fluency dan orisinil. Pada indikator fluency, kelas C mendapat persentase skor 3 yang lebih tinggi yaitu sebesar 66,67, sedangkan kelas B persentase yang paling tinggi terletak pada perolehan skor 2 yaitu sebesar 69,23\%.

Indikator flexibility menunjukkan hasil kelas B mendapat persentase skor 3 yang lebih tinggi yaitu sebesar 92,31\%, sedangkan kelas B mendapatkan persentase sebesar 82,05\%. Pada indikator orisinil, kelas C mendapat persentase yang lebih tinggi yaitu 30,77\%, sedangkan kelas B mendapat persentase sebesar 92,31\% pada skor 2. Jabaran dari indikator elaboratif menyatakan kelas B mendapatkan persentase 100\%, kelas C mendapatkan persentase sebesar 69,23\%. Tabel 1 menjelaskan persentase perolehan skor tertinggi dari masing-masing indikator di tiap kelas. Gambar 1 menunjukkan grafik perolehan skor masing-masing kelas secara lengkap. 
Tabel 1. Persentase Perolehan Skor Tertinggi Kemampuan Berpikir Kreatif per Indikator

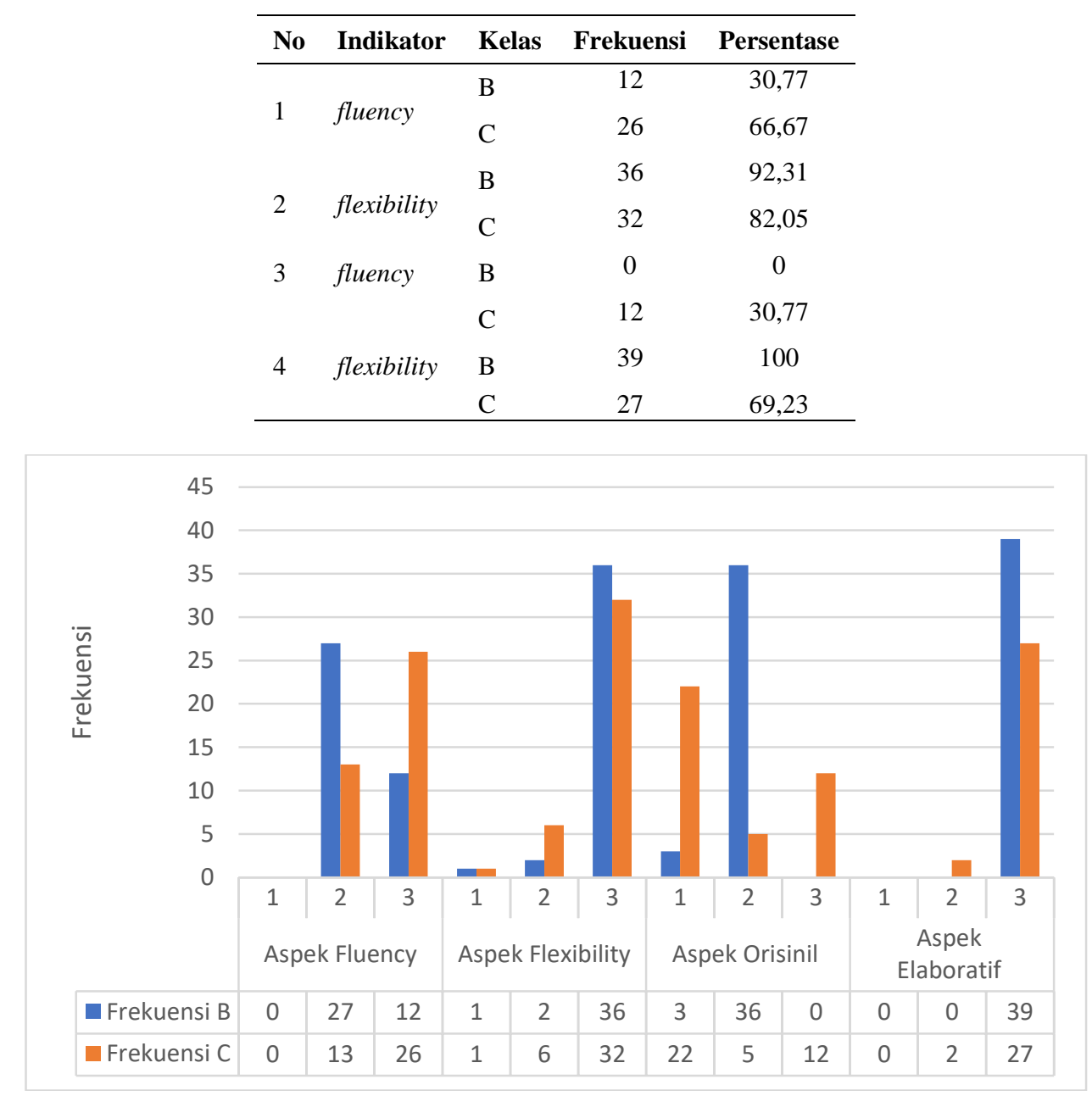

Gambar 1. Grafik Perolehan Skor Kemampuan Berpikir Kreatif per Indikator

Analisis Indikator Komunikasi

Kemampuan komunikasi dinilai dari tiga aspek yaitu kemampuan komunikasi lisan, komunikasi tulisan, dan mendengarkan. Berdasarkan hasil penelitian didapatkan hasil bahwa kemampuan komunikasi lisan kelas B pada indikator berbicara di depan kelas, gaya komunikasi dan ceramah yang efektif mendapatkan persentase yang lebih tinggi dari kelas $\mathrm{C}$, yaitu $95,51 \%, 97,44 \%$, dan $88,64 \%$. Kelas C mendapatkan persentase yang lebih tinggi untuk indikator bersikap asertif yaitu sebesar 97,44\%. Untuk kemampuan komunikasi tulisan kelas B memperoleh skor rata-rata indikator yang lebih tinggi daripada kelas C yaitu sebesar 50\% untuk indikator sistematika tulisan dan 65\% untuk indikator kejelasan kalimat.

Pada kemampuan mendengarkan didapatkan data kelas B mendapatkan persentase yang lebih tinggi pada semua indikator yaitu perhatian pada lawan bicara sebesar $100 \%$, parafrasa sebesar $92,31 \%$, sintaksis dan pola sebesar $92,31 \%$, dan memberi umpan balik sebesar 97,44\%. Tabel 2 memaparkan persentase perolehan skor tertinggi setiap indikator kemampuan komunikasi di masing-masing kelas. Persentase skor tertinggi kemampuan komunikasi lisan, mendengarkan, dan komunikasi tulisan secara berurutan ditunjukkan oleh Tabel 2, 3, dan 4. Gambar 2 dan 3 menunjukkan grafik perolehan skor untuk masingmasing aspek kemampuan komunikasi perindikator pada setiap kelas. 
Tabel 2. Persentase Perolehan Skor Tertinggi Komunikasi Lisan per Indikator

\begin{tabular}{|c|c|c|c|c|c|}
\hline Aspek & Indikator & Prediktor & Kelas & Frekuensi & Persentase \\
\hline \multirow{28}{*}{$\begin{array}{c}\text { Keterampilan } \\
\text { berbicara / } \\
\text { Komunikasi } \\
\text { lisan }\end{array}$} & Keterampilan berbicara di depan kelas & Tata Bahasa & B & 39 & 100 \\
\hline & & & $\mathrm{C}$ & 39 & 100 \\
\hline & & Kosakata & B & 35 & 89,74 \\
\hline & & & $\mathrm{C}$ & 34 & 87,18 \\
\hline & & Tempo & B & 38 & 97,44 \\
\hline & & & $\mathrm{C}$ & 36 & 92,31 \\
\hline & & Hal ambigu & B & 37 & 94,87 \\
\hline & & & $\mathrm{C}$ & 38 & 97,44 \\
\hline & Gaya komunikasi & Kesan bicara & B & 38 & 97,44 \\
\hline & & & $\mathrm{C}$ & 33 & 84,62 \\
\hline & Bersikap asertif & Terbuka terhadap pendapat & B & 33 & 84,62 \\
\hline & & & $\mathrm{C}$ & 37 & 94,87 \\
\hline & & Tidak memaksakan kehendak & B & 34 & 87,18 \\
\hline & & & $\mathrm{C}$ & 39 & 100 \\
\hline & Ceramah yang efektif & Interaksi audience & B & 30 & 76,92 \\
\hline & & & $\mathrm{C}$ & 16 & 41,03 \\
\hline & & Tujuan & B & 38 & 97,44 \\
\hline & & & $\mathrm{C}$ & 21 & 53,85 \\
\hline & & Gesture & B & 38 & 97,44 \\
\hline & & & $\mathrm{C}$ & 18 & 46,15 \\
\hline & & Bahasa & B & 30 & 76,92 \\
\hline & & & $\mathrm{C}$ & 37 & 94,87 \\
\hline & & Tata ceramah & B & 38 & 97,44 \\
\hline & & & $\mathrm{C}$ & 39 & 100 \\
\hline & & Ide pendukung & B & 30 & 76,92 \\
\hline & & & $\mathrm{C}$ & 14 & 35,90 \\
\hline & & Media & B & 38 & 97,44 \\
\hline & & & $\mathrm{C}$ & 37 & 94,87 \\
\hline
\end{tabular}

Tabel 3. Persentase Perolehan Skor Tertinggi Komunikasi Tulisan per Indikator

\begin{tabular}{|c|c|c|c|c|c|}
\hline Aspek & Indikator & Prediktor & Kelas & Frekuensi & Persentase \\
\hline \multirow{8}{*}{$\begin{array}{l}\text { Keterampilan } \\
\text { berkomunikasi } \\
\text { melalui tulisan }\end{array}$} & \multirow{4}{*}{ Sistematika penulisan } & \multirow[b]{2}{*}{ Kesesuian sistematika } & B & 39 & 100 \\
\hline & & & $\mathrm{C}$ & 0 & 0 \\
\hline & & \multirow[b]{2}{*}{ Kutipan dan daftar rujukan } & B & 0 & 0 \\
\hline & & & $\mathrm{C}$ & 0 & 0 \\
\hline & \multirow{4}{*}{$\begin{array}{l}\text { Kejelasan } \\
\text { kalimat/paragraf }\end{array}$} & \multirow[b]{2}{*}{ Struktur kalimat } & B & 21 & 53,85 \\
\hline & & & $\mathrm{C}$ & 0 & 0 \\
\hline & & \multirow{2}{*}{ Kalimat } & B & 30 & 76,92 \\
\hline & & & $\mathrm{C}$ & 0 & 0 \\
\hline
\end{tabular}


Tabel 4. Persentase Perolehan Skor Tertinggi Kemampuan Mendengarkan per Indikator

\begin{tabular}{lllccc}
\hline Aspek & Indikator & Prediktor & Kelas & Frekuensi & Persentase \\
\hline & \multirow{2}{*}{ Perhatian lawan bicara } & Kata atau gesture & B & 39 & 100 \\
& & & C & 39 & 100 \\
& Parafrasa & Kalimat sendiri & B & 36 & 92,31 \\
Keterampilan & & & C & 24 & 61,54 \\
mendengarkan & \multirow{2}{*}{ Sinteksis tema dan pola } & Tema & B & 36 & 92,31 \\
& & Umpan balik & C & 26 & 66,67 \\
& Umpan balik & & B & 38 & 97,44 \\
& & & C & 35 & 89,74
\end{tabular}

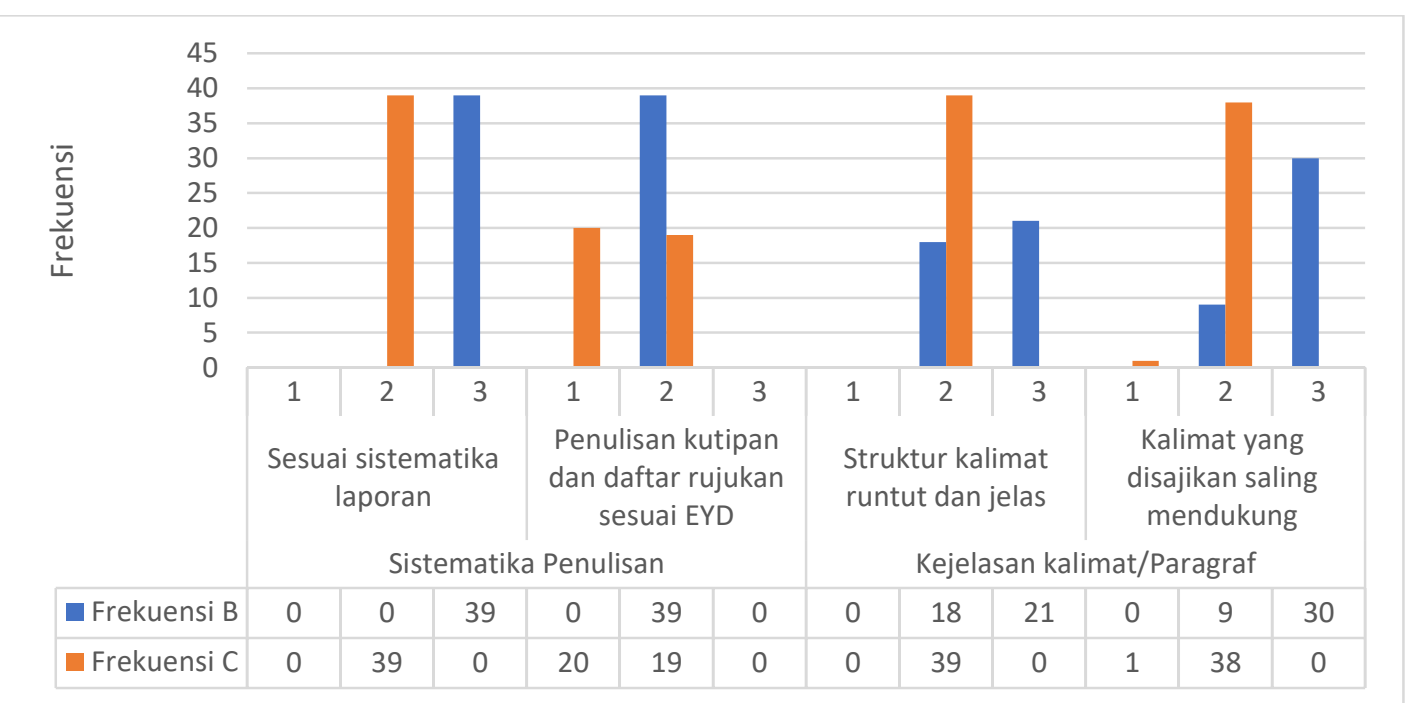

Gambar 2. Grafik Perolehan Skor Kemampuan Komunikasi Tulisan per Indikator

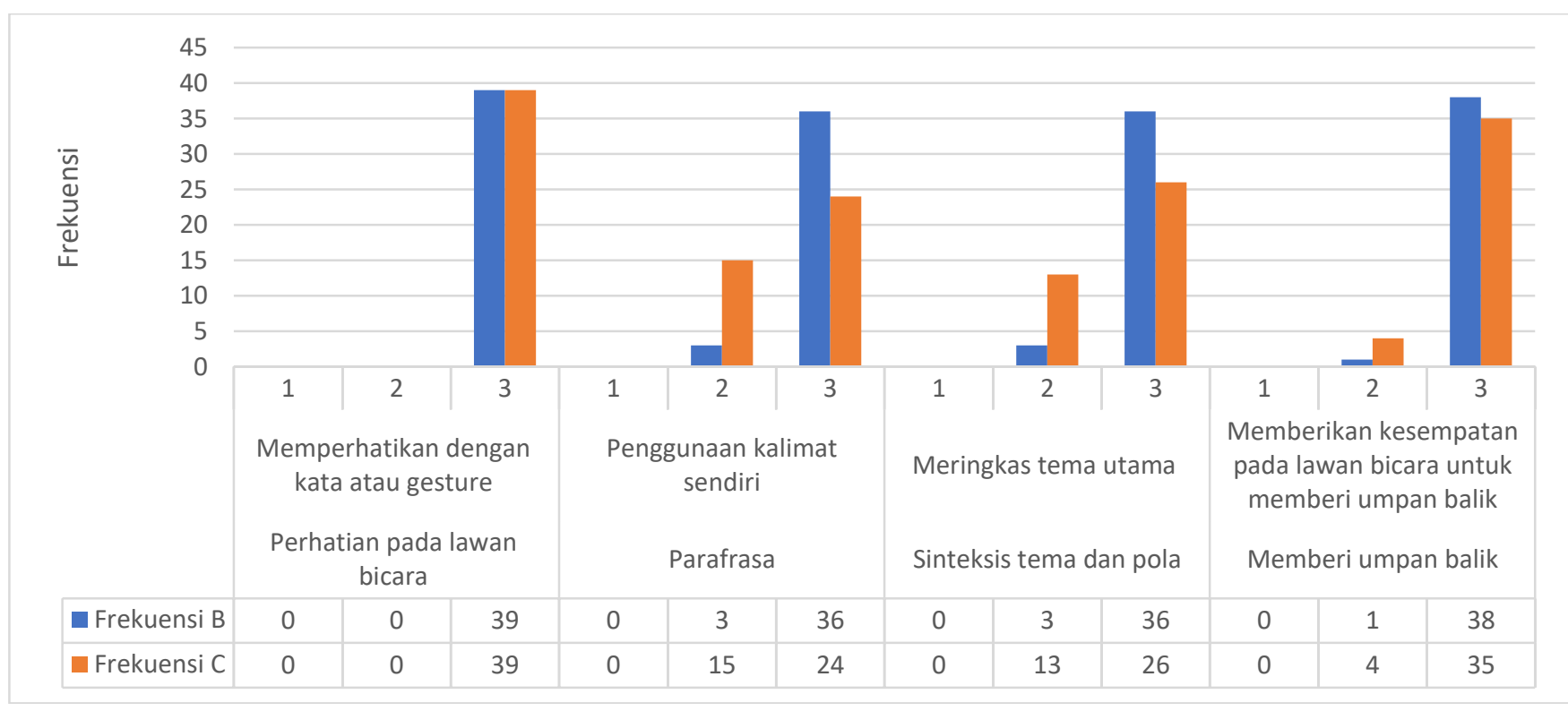

Gambar 3. Grafik Perolehan Skor Kemampuan Mendengarkan per Indikator 


\section{Perbedaan Kemampuan Berpikir Kreatif dan Komunikasi pada Mahasiswa S1 PTI}

Uji t akan digunakan sebagai teknik analisis untuk melihat perbedaan tingkat kemampuan berpikir kreatif dan komunikasi pada mahasiswa PTI. Prasyarat analisis yang diterapkan adalah normalitas dan homogenitas. Tabel 4 menunjukkan uji normalitas dari aspek kemampuan berpikir kreatif dan komunikasi. Tabel 5 memaparkan hasil uji homogenitas pada kemampuan berpikir kreatif dan komunikasi. Tabel 6 menjabarkan hasil perhitungan perbedaan kemampuan berpikir kreatif dan komunikasi pada masing-masing kelas. Berdasarkan data tabel 6 maka dapat ditarik simpulan kelas B dan C memiliki kemampuan berpikir kreatif dan kemampuan komunikasi yang berbeda.

Tabel 4. Hasil Uji Normalitas

\begin{tabular}{lccl}
\hline \multicolumn{1}{c}{ Aspek } & Hasil Uji & Kriteria Sig. & Kesimpulan \\
\hline Berpikir kreatif & 0,766 & $>0,05$ & Normal \\
Komunikasi & 0,189 & $>0,05$ & Normal \\
\hline
\end{tabular}

Tabel 5. Hasil Uji Homogenitas

\begin{tabular}{lccl}
\hline \multicolumn{1}{c}{ Aspek } & Hasil Uji & Kriteria Sig. & Kesimpulan \\
\hline Berpikir kreatif & 0,076 & $>0,05$ & Homogen \\
Komunikasi & 0,127 & $>0,05$ & Homogen \\
\hline
\end{tabular}

Tabel 6. Hasil T-test

\begin{tabular}{lccc}
\hline \multicolumn{1}{c}{ Aspek } & Hasil Uji & Kriteria Sig. & Kesimpulan \\
\hline Berpikir kreatif & 0,020 & $<0,05$ & Terdapat perbedaan \\
Komunikasi & 0,014 & $<0,05$ & Terdapat perbedaan \\
\hline
\end{tabular}

\section{PEMBAHASAN}

\section{Analisis Indikator Kemampuan Berpikir Kreatif dan Komunikasi} Analisis Indikator Kemampuan Berpikir Kreatif

Indikator yang dijadikan acuan dalam pembuatan instrumen tes adalah indikator berpikir kreatif menurut Munandar (2008). Masing-masing indikator akan diuraikan menjadi butir soal yang dapat mengukur kemampuan berpikir kreatif mahasiswa. Setiap sajian soal berpikir kreatif tidak selalu menggunakan indikator yang sama. Soal yang diujikan pada subjek coba terkait penelitian ini terdiri empat aspek, yaitu fluency, flexibility, orisinil, dan elaboratif.

Indikator fluency mengukur kemampuan untuk menghasilkan sejumlah ide besar (Guilford, 2017). Berdasarkan hasil test kemampuan berpikir kreatif, aspek fluency pada masing-masing kelas tergolong rendah. Pada kelas B 30,77\% mahasiswa mendapatkan skor tertinggi yaitu 3, begitu pula kelas C yang hanya sebesar 30,77\%. Pada kelas B frekuensi terbanyak ada pada skor 2 yaitu 69,23\%, sedangkan pada kelas C sebesar 33,33\%. Dari soal perancangan yang diberikan mahasiswa masih cenderung menjiplak contoh rancangan sehingga tidak terdapat ide/gagasan baru. Fluency pada diri seseorang ditandai dengan banyaknya variasi jawaban atau solusi (Husamah, 2015b, 2015a; Marhami, 2015). Fluency dapat dikembang jika mahasiswa diorientasikan pada kegiatan yang lebih terorganisasi dan menarik sehingga menumbuhkan keingintahuan (Murtafiah, 2017).

Indikator flexibilty mengukur kemampuan untuk menghasilkan variasi gagasan yang luas (Guilford, 2017). Sesuai dengan hasil skor test, indikator flexibility pada kelas B dan C mendapatkan skor yang tinggi yaitu 92,31\% dan 82,05\%. Dari rancangan soal yang diberikan, mahasiswa sudah dapat memberikan sedikit variasi pada penerapan penggunaan alamat jaringan agar tidak sesuai contoh. Mahasiswa mencoba pemberian alamat jaringan sesuai dengan apa yang telah dirancang. Flexibility pada diri seseorang akan berkembang jika model pembelajaran dapat merangsangnya untuk membentuk suatu alternatif yang baru (Husamah, 2015b, 2015a; Marhami, 2015).

Indikator orisinil mengukur kemampuan untuk menghasilkan ide yang luar biasa (Guilford, 2017). Berdasarkan hasil test dapat dilihat bahwa perolehan skor tertinggi indikator orisil pada masing-masing kelas sangat rendah yaitu pada kelas $\mathrm{C}$ $30,77 \%$, sedangkan kelas B 0\% (skor 1 sebanyak 56,14\%). Dapat disimpulkan bahwa orisinalitas masih sangat rendah. Orisinil berkaitan dengan kemampuan untuk melahirkan gagasan baru yang bersifat unik (Marhami, 2015). Model pembelajaran yang digunakan perlu mengembangkan atau melatih cara berpikir mahasiswa agar ide baru dapat tercipta.

Indikator elaboration mengukur kemampuan yang mengembangkan ide dan menghasilkan secara flesh out gagasan (Guilford, 2017). Sesuai dengan hasil test dapat dilihat bahwa kelas C mendapat perolehan persentase skor tertinggi sebesar 100\% sedangkan kelas C sebesar 69,23\%. Aktivitas elaborasi dapat terlihat melalui penambahan detail atau sesuatu yang baru pada produk agar lebih menarik (Husamah, 2015b; Marhami, 2015).

Pembelajaran pada perguruan tinggi tidak membiasakan pebelajar untuk berpikir apakah pennyebabnya dan bagaimana akibatnya. Pebelajar cenderung hanya mematuhi instruksi dosen yang belum mengarahkan pembelajaran untuk memecahkan masalah dan berpikir tingkat tinggi (Fadli, 2010; Shakir, 2009). Menurut Marhami (2015), aktivitas yang dapat menumbuhkan keterampilan berpikir kreatif yaitu (1) mengajukan pertanyaan; (2) menimbang informasi; (3) mencari hubungan dalam perbedaan; (4) menerapkan ide untuk kondisi yang berbeda-beda. 
Pembelajaran yang diterapkan pada matakuliah KDJK adalah Blended Project Based Learning. Penggabungan dua model ini diharapkan dapat membawa dampak positif. Kemampuan berpikir kreatif mahasiswa jika dilihat dari detail indikator secara umum memberikan skor yang cukup tinggi pada penggunaan model pembelajaran ini. Untuk beberapa indikator masih perlu di tingkat lagi sehingga diperlukan beberapa aktivitas tambahan yang dapat meningkatkan hal tersebut.

\section{Analisis Indikator Komunikasi}

Indikator yang menjadi patokan dalam penyususnan instrumen lembar observasi adalah indikator kemampuan komunikasi menurut Santrock (2014), Iriantara (2014) dan Lunenburg (2010). Kemampuan komunikasi terbagi menjadi tiga yaitu kemampuan komunikasi lisan, komunikasi tulisan, dan mendengarkan. Secara umum, sebagian besar semua indikator komunikasi telah mendapat skor yang tinggi. Akan tetapi, terdapat beberapa hal yang perlu diperhatikan pada masing-masing kemampuan komunikasi. Pada kemampuan komunikasi lisan, hal yang perlu diperhatikan yaitu dua sub indikator pada indikator ceramah yang efektif. Indikator berbicara langsung pada audience mendapat persentase yang rendah yaitu untuk kelas B sebesar $76,92 \%$, sedangkan kelas C sebesar $41,03 \%$. Sub indikator lain yang mendapatkan skor rendah yaitu menunjukkan bukti pendukung yaitu sebesar 76,92\% untuk kelas B dan 35,90\% untuk kelas C.

Agar komunikasi lisan efektif, perlu diperhatikan mengenai pengenalan sasaran komunikasi, penggunaan media komunikasi, tujuan pesan komunikasi, dan peran komunikator (Wisman, 2017). Penggunaan Blended Project Based Learning telah memfasiltasi beberapa hal tersebut dengan kegiatan presentasi secara offline dan pembelajaran aktivitas kelompok yang rutin. Terkait dengan kekurangan yaitu pada interaksi dengan audience dan pengungkapan tujuan dapat dijadikan koreksi untuk perbaikan Blended Project Based Learning yang telah diterapkan.

Pada kemampuan komunikasi tulisan, semua skor yang ditunjukkan kelas $\mathrm{C}$ sangat rendah, perolehan skor didominasi oleh skor dua dengan rincian indikator sistematika 74,36\%, sedangkan indikator kejelasan kalimat 98,7\%. Hal ini sangat perlu mendapat perhatian. Setelah ditelusuri penyebab kelas $\mathrm{C}$ mendapat persentase yang sangat rendah adalah perbedaan waktu kuliah tatap muka. Laporan yang dinilai adalah laporan yang langsung dibuat pada kegiatan tatap muka karena waktu kurang maka penulisan laporan pada kelas C cenderung kurang baik. Senada dengan yang diungkapkan oleh Andayani dan Kumara (1999) dan Yaniasti (2011) bahwa dalam bentuk komunikasi tulisan perlu diperhatikan waktu pengerjaan tulisan sehingga hal ini patut diperhatikan untuk perbaikan model Blended Project Based Learning selanjutnya.

Kemampuan mendengarkan menunjukkan persentase yang baik pada semua indikator. Rata-rata semua indikator pada kelas B adalah $96 \%$, sedangkan kelas C adalah $79 \%$. Indikator yang mendapat persentase rendah adalah parafrasa (Kelas B $92,31 \%$, sedangkan kelas C 61,54\%) dan sinteksis tema (Kelas B 92,31\% dan kelas C 66,67\%). Individu di Indonesia masih banyak berperan sebagai pendengar pasif (Martoredjo, 2014; Sari, 2016). Aktivitas pembelajaran perlu mengarahkan pebelajar agar dapat membiasakan untuk mendengarkan secara aktif. Aktivitas tersebut, meliputi (1) menguraikan kata sendiri sesuai dengan ide; (2) tidak hanya mengandalkan daya ingat, tetapi bersama dengan aktivitas merekam, menulis, dan menyimpan informasi dalam bentuk lain; (3) menghindari pendengar secara selektif dengan mencoba fokus pada pembicara dan menganalisa apa yang didengar (Sari, 2016).

\section{Perbandingan Tingkat Kemampuan Berpikir Kreatif dan Komunikasi}

Berpikir kreatif menyatakan cara untuk menjalankan sesuatu yang bercirikan (1) kefasihan pengajuan gagasan; (2) fleksibel terhadap perubahan; (3) kelancaran membuat ide; (4) keaslian menyusun sesuatu yang baru; (5) elaborasi ide lain. Namun, pembelajaran dewasa ini hanya bersifat hafalan dan tidak diarahkan pada berpikir tingkat tinggi (Fadli, 2010; Shakir, 2009). Penggunaan model pembelajaran yang sesuai serta iklim belajar yang mendukung perlu diperhatikan agar kemampuan berpikir kreatif dapat berkembang (Sabirin, 2016).

Hasil uji t menunjukkan kelas B dan C memiliki kemampuan berpikir kreatif yang berbeda. Namun, secara garis besar dapat disimpulkan bahwa kelas B lebih kreatif dari hasil analisis indikator dan sub indikator yang dilakukan. Husamah (2015) pada penelitiannya mengungkapkan bahwa Project Based Learning yang telah dikombinasi menunjukkan rata-rata berpikir kreatif yang tinggi pada kelas eksperimen. Pembelajaran berbasis juga dapat mengarahkan pebelajar pada aktivitas yang bermakna sehingga cocok untuk matakuliah yang mengajarkan pengetahuan dan keterampilan (Rati, Kusmaryatni, \& Rediani, 2017; Sabirin, 2016).

\section{Perbandingan Tingkat Komunikasi}

Agar komunikasi antara komunikan dan komunikator berjalan dengan baik maka diperlukan keterampilan komunikasi yang efektif pada setiap individu. Mahasiswa memiliki kemampuan komunikasi yang rendah dikarenakan pembelajaran yang masih berpusat pada dosen. Mahasiswa masih difungsikan sebagai peserta pasif dari proses pembelajaran.

Hasil uji t menyatakan bahwa terdapat perbedaan hasil kemampuan komunikasi antara kelas B dan C. Kemampuan komunikasi dua offering tersebut hampir sama. Penelitian Zainuddin dan Keumala (2018) menyatakan bahwa komunikasi akan meningkat jika digunakan model pembelajaran Blended. Komunikasi yang efektif dalam pendidikan dapat dilakukan jika semua unsur yang terlibat dapat ikut serta dalam aktivitas yang mendorong penggunaan komunikasi efektif (Andayani \& Mada, 1999; Yaniasti, Ekonomi, \& Singaraja, 2011). Dalam pembelajaran Blended yang telah dimodifikasi dengan Project Based komunikasi dapat terjalin dengan terarah (Husamah, 2015a). 


\section{SIMPULAN}

Berdasarkan penelitian ini dapat ditarik kesimpulan yaitu (1) sebagian besar frekuensi perolehan indikator berpikir kreatif dan komunikasi pada kelas B lebih tinggi daripada kelas C; (2) rata-rata kelas B mempunyai tingkat berpikir kreatif $(88,20)$ dan komunikasi $(89,51)$ lebih tinggi dibandingkan kelas $\mathrm{C}$.

Saran yang diajukan setelah dilakukan penelitian ini yaitu penerapan atau penggunaan Blended Project Based Learning dalam matakuliah KDJK memerlukan beberapa penyesuaian terkait dengan karakteristik siswa dan perubahan materi. Integrasi dengan keterampilan abad 21 yaitu kemampuan berpikir kritis, berpikir kreatif, komunikasi, dan kolaborasi juga perlu diperhatikan.

\section{DAFTAR RUJUKAN}

Alias, S. N., \& Ibrahim, F. (2015). The Level of Mastering Forces in Equilibrium Topics by Thinking Skills. International Journal of Multicultural and Multireligious Understanding, 2(5), 18-24. DOI: http://dx.doi.org/10.18415/ijmmu.v2i5.

Andayani, B., \& Mada, U. G. (1999). Meningkatkan Keterampilan Komunikasi Tertulis melalui Pendekatan Perspektif. Psikologi, 1(1), 41-50.

Fadli. (2010). Meningkatkan Kemampuan Berpikir Kritis dan Kemandirian Belajar Matematika pada Mahasiswa melalui Pembelajaran Generatif. Perspektif Ilmu Pendidikan, 22(13).

Guilford, J. P. (2017). Creativity: Yesterday, Today and Tomorrow. Journal of Creative Behaviour, 1(1), 3-14.

Husamah. (2015a). Blended Project Based Learning: Metacognitive Awareness of Biology Education New Students. Journal of Education and Learning, 9(4), 274-281.

Husamah. (2015b). Thinking Skills for Environmental Sustainability Perspective of New Students of Biology Education Department Through Blended Project Based Learning. Jurnal Pendidikan IPA Indonesia https://doi.org/10.15294/jpii.v4i2.3878

Iriantara, Y. (2014). Komunikasi Pembelajaran: Interaksi Komunikatif dan Edukatif di dalam Kelas. Bandung: Simbiosa Rekatama Media.

Johnson, P. (2009). The 21st Century Skills Movement. Educational Leadership. Educational Leadership, 67(1), 11.

Lunenburg, F. C. (2010). Rendir cuentas en el ámbito de la educación. Communication: The Process, Barriers, and Improving Effectiveness, 1(1), 1-11. Retrieved from http://unesdoc.unesco.org/images/0026/002610/261016S.pdf

Marhami. (2015). Membangun Kemampuan Berpikir Kreatif dan Komunikasi Matematis melalui Pembelajaran Problem Based Learning. In Seminar Nasional Matematika dan Pendidikan Matematika UNY 2015 (pp. 149-154).

Martoredjo, N. T. (2014). Dalam Komunikasi Interpersonal. Humaniora, 5(1), 501-509.

Murtafiah, W. (2017). Profil Kemampuan Berpikir Kreatif Mahasiswa dalam Mengajukan Masalah. Jurnal Ilmiah Pendidikan Matematika, 5(2), 73-81. https://doi.org/10.25273/jipm.v5i2.1170

Pheeraphan, N. (2015). Enhancement of the 21st Century Skills for Thai Higher Education by Integration of ICT in Classroom Enhancement of the 21 st Century Skills for Thai Higher Education by Integration of ICT in Classroom. Procedia - Social and Behavioral Sciences, 103(September), 365-373. https://doi.org/10.1016/j.sbspro.2013.10.346

Rati, N. W., Kusmaryatni, N., \& Rediani, N. (2017). Model Pembelajaran Berbasis Proyek Kreativitas. Jurnal Pendidikan Indonesia, 6(1), 60-71.

Sabirin, F. (2016). Peningkatan Kreativitas dan Kolaborasi Mahasiswa melalui Pembelajaran Berbasis Proyek pada Matakuliah Pemrograman di Politeknik Negeri Pontianak. Jurnal Pendidikan Informatika dan Sains, 5(2), 195-211.

Santrock, J. W. (2012). Life-Span Development: Perkembangan Masa Hidup Edisi Ketigabelas Jilid 2. New York: Erlangga.

Sari, A. W. (2016). Pentingnya Keterampilan Mendengar Dalam Menciptakan Komunikasi yang Efektif. Jurnal EduTech, 2(1), $1-10$.

Shakir, R. (2009). Soft Skills at the Malaysian Institutes of Higher Learning. Asia Pacific Educ. Rev. (2009), 10(10), 309-315. https://doi.org/10.1007/s12564-009-9038-89

Slameto. (2014). Developing Critical Thinking Skills through School Teacher Training "Training and Development Personnel" Model and Their Determinants of Success. International Journal of Information and Education Technology, 4(2), 161166. https://doi.org/10.7763/IJIET.2014.V4.390

Thompson, C. (2011). Critical Thinking Across the Curriculum. Humanities and Social Science, 1(9), 1-7. https://doi.org/10.1007/s11245-016-9401-4

Wisman, Y. (2017). Komunikasi Efektif Dalam Dunia Pendidikan. Jurnal Nomosleca, 3(2), 646-654.

Yaniasti, N. L., Ekonomi, F., \& Singaraja, U. (2011). Widyatech Jurnal Sains dan Teknologi, 11(1), 1-25.

Zubaidah, S. (2016). Keterampilan Abad ke-21 : Keterampilan yang Diajarkan. In Isu-isu Strategis Pembelajaran MIPA Abad $21,1-17$. 